\title{
Geïntegreerde, kwalitatiewe en kwantitatiewe beroepsvoorligting en beroepskonstruksie vir'n aandagafleibare seun met tegniese belangstelling en aanleg lei tot positiewe resultate
}

\begin{abstract}
Author:
Jacobus G. Maree ${ }^{1}$

Affiliation:

${ }^{1}$ Faculty of Education,

University of Pretoria,

South Africa

Correspondence to:

Kobus Maree

Email:

kobus.maree@up.ac.za

Postal address:

University of Pretoria,

Groenkloof Campus,

Lynnwood Road, Hatfield,

Pretoria 0028, South Africa

Dates:

Received: 17 June 2014

Accepted: 02 July 2014

Published: 14 Oct. 2014

How to cite this article:

Maree, J.G., 2014,

'Geïntegreerde, kwalitatiewe en kwantitatiewe

beroepsvoorligting en

beroepskonstruksie vir'n

aandagafleibare seun met

tegniese belangstelling en

aanleg lei tot positiewe

resultate', Suid-Afrikaanse

Tydskrif vir Natuurwetenskap

en Tegnologie 33(1), Art.

\#1183, 11 pages. http://

dx.doi.org/10.4102/satnt.

v33i1.1183

\section{Copyright:}

(C) 2014. The Authors.

Licensee: AOSIS

OpenJournals. This work

is licensed under the

Creative Commons

Attribution License.

Hierdie artikel beskryf die waarde van beroepskonstruksie aan die hand van 'n geïntegreerde, kwalitatiewe en kwantitatiewe benadering vir 'n leerder met tegniese belangstelling en aanleg wat met aandagafleibaarheid presenteer. Die navorsingsontwerp (kwalitatief) behels ' $n$ intrinsieke, instrumentele gevalstudie om die deelnemer diepgaande en in sy natuurlike konteks te begryp. Die deelnemer is 'n 17-jarige jong man wat geëvalueer is met die oog op beroepsvoorligting. Daar was dus sprake van sowel doelsteekproefneming as geriefsteekproefneming. Evaluasie is na'n tussenpose van 2 jaar herhaal met terugvoer ná afloop van elke assessering. Data is met behulp van kwalitatiewe, sowel as kwantitatiewe tegnieke ingesamel (kwantitatief: die Jung-persoonlikheidsvraelys, die Myers-Briggs Type Indicator, die Differential Aptitude Tests en die Rothwell-Miller-belangstellingsvraelys, die Maree Career Matrix; kwalitatief: ' $n$ collage, die Beroepsbelangstellingsprofiel, lewenslyn, vroeë herinneringe, asook die lewensverhaaltegnieke). Tydens die tweede evaluering het sy belangstellings grotendeels stabiel gebly; sy aanlegte was oor die algemeen dieselfde as voorheen, en dit het inderdaad geblyk dat sy studie-oriëntasie verbeter het. Verder het sy neiging tot introversie verander na 'n relatief sterk neiging tot ekstroversie. Kwalitatiewe evaluering is grotendeels voltrek aan die hand van refleksiwiteit, of herhaalde refleksie oor sy eie refleksie, en het 'n dormante bereidwilligheid aan die lig gebring om harder te werk en meer aktief aan sy selfkonstruksie deel te neem en aan sy ontluikende beroepslewensverhaal te skryf. Enkele aanbevelings is gemaak om hom in staat te stel om hierdie bereidwilligheid in die praktyk te laat realiseer. In hierdie geval het 'n kwalitatiewe en kwantitatiewe benadering vir 'n aandagafleibare leerder met 'n sterk tegniese aanleg 'n positiewe bydrae in die leerder se lewe gemaak. Omvattende navorsing in groepsverband is nodig.

Integrated, qualitative and quantitative career counselling and career construction with a learner with a technical interest and aptitude who presents with attention deficit leads to positive results. This article describes the value of career construction based on an integrating qualitative and quantitative approach for a learner with a technical interest and aptitude who presents with attention deficit. The qualitative research design entails an intrinsic, instrumental case study aimed at gaining an in-depth understanding of the participant in his natural context. The participant was a 17 year old young man who was assessed with a view to career counselling. Hence both purpose and convenience sampling were used. Assessment was repeated after a 2-year interval with feedback following each assessment. Data was gathered by means of qualitative, as well as quantitative techniques (quantitative: the Jung Personality Questionnaire, the Myers-Briggs Type Indicator, the Differential Aptitude Tests and the Rothwell-Miller Interest Blank, the Maree Career Matrix; qualitative: a collage, the Career Interest Profile, life line, early memories, as well as the life story techniques). In the second assessment his interests remained largely stable; his aptitudes were generally the same as before and his study orientation seemed to have improved. Furthermore, his tendency towards introversion had changed to a relatively strong tendency towards extroversion. Qualitative assessment was done largely on the basis of reflexivity, or repeated reflection about his own reflection, and revealed a dormant willingness to work harder and to participate more actively in his self-construction and in the writing down of his emerging career life story. Some recommendations were made to enable him to demonstrate this willingness in practice. The results cannot be generalised, but it seems that career construction based on a qualitative and quantitative approach for a learner with an attention deficit and a strong technical aptitude may potentially contribute to substantial changes in the learner's life. Comprehensive research in a group context is necessary. 


\section{'n Geïntegreerde kwalitatiewe en kwantitatiewe benadering tot beroepsvoorligting}

Afgesien van 'n verwante artikel (Maree 2012a), wat sowat 2 jaar gelede oor die onderwerp geskryf is, is weinig in Suid-Afrika gepubliseer oor die nuwe benadering tot beroepsvoorligting. Hierdie artikel is 'n poging om aandag aan daardie leemte te gee.

Met die frase 'geïntegreerde kwalitatiewe en kwantitatiewe benadering tot beroepsvoorligting' word bedoel dat daar weg beweeg word van 'n oorheersend kwantitatiewe (of positivistiese) benadering tot beroepsvoorligting wat feitlik eksklusief op die gebruik van gestandaardiseerde toetse berus. Ondanks die algemene persepsie dat 'positivistiese' toetsuitslae sukses in bepaalde studierigtings akkuraat en korrek kan voorspel en finale ('definitive') antwoorde op leerders of studente se beroepskeuseverwante vrae en presiese planne met hul lewens verskaf, bestaan daar wêreldwyd eenstemmigheid dat dit bepaald nie die geval is nie (Hartung 2010; Maree 2010). Dit is noodsaaklik om ook subjektiewe inligting rakende toetslinge te bekom om hulle te bemagtig om ingeligte besluite te neem, eerder as om feitlik eksklusief op aanleg, belangstellings en (ander) persoonlikheidsaspekte te fokus. Sulke subjektiewe inligting word ingesamel deur middel van onderhoude wat daarop gerig is om 'n vollediger tapisseriebeeld van 'n individuele persoon te bekom. Ná afloop hiervan word die lewensverhale wat bekom is, ontleed ten einde persone se kernlewenstemas in hul narratiewe te identifiseer (Savickas 2007).

Hedendaagse beroepsvoorligting lê sterk klem op 'n benadering wat kwalitatiewe assessering (d.i. die gebruik van verhalende inligting wat met behulp van kwalitatiewe tegnieke bekom word), sowel as kwantitatiewe metodes insluit (Maree 2012b, 2013). Die twee 'stelle' inligting (kwalitatief en kwantitatief) word geïntegreer om te verhoed dat toetslinge nie slegs kwantitatiewe 'toetsuitslae' (wat gewoonlik feitlik eksklusief deur sielkundige toetse bekom word) in ag neem wanneer hulle vakkeuses en beroepskeuses maak nie. Kwalitatiewe inligting word bekom deur middel van die toepassing van nie-gestandaardiseerde vraelyste soos die Beroepskonstruksievraelys (Savickas 2011), die Beroepsbelangstellingsprofiel (Maree 2012c), lewenslyne, collages en die Vroeë Herinneringetegniek (Maree 2013). Deur die twee stelle inligting te integreer, word toetslinge bemagtig om oor hul eie refleksies te besin (refleksiwiteit word gefasiliteer) en hulself as't ware self te adviseer. Toetslinge word deurlopend versoek om te 'reflekteer oor hul eie refleksies', en die beroepsvoorligter te laat weet watter lewenstemas hulle uit hul eie response kan identifiseer. Die beroepsvoorligter verskaf slegs minimale interpretasie ten einde toetslinge in staat te stel om self sentrale lewenstemas uit hul narratiewe te identifiseer en derhalwe na hulself te luister.

In die volgende paragrawe konsentreer ek op die Suid-Afrikaanse onderwysstelsel met spesifieke fokus op die behoefte aan ingenieurs, ingenieurstegnici en vakmanne, asook op die verskynsel dat talle leerders enersyds met aandagafleibaarheid in een of ander vorm presenteer en andersyds oor bogemiddelde tegniese belangstelling en aanleg beskik. Daarna omskryf ek die term aandagtekort(hiperaktiwiteit)versteuring (AT[H]V) en belig ek die teoretiese en konseptuele raamwerk vir die interpretasie van my data.

\section{Perspektief op die Suid-Afrikaanse onderwysstelsel oor die algemeen en die behoefte aan ingenieurs, ingenieurstegnici en vakmanne in besonder}

Baie is reeds geskryf oor die uitdagings wat die SuidAfrikaanse onderwysstelsel knel. Ontoereikende prestasie (maar dikwels ook prestasie in ontoepaslike studierigtings) op skool vlak sowel as tersiêre vlak benadeel leerders se selfkonstruksie (sien verder aan) (Kraak 2008, 2010; Maree 2013; Savickas 2008), en gevolglik ook hul kans om by die gemeenskap in te skakel en suksesvolle lewens te ontwerp. Dit bederf ook hul geleentheid om maatskaplike bydraes te lewer en verskraal uiteindelik hul kans om tot die nasionale ekonomie by te dra.

Die ingenieursberoep is die beroep waarin die grootste tekorte in Suid-Afrika voorkom (Datum recruitment services 2013). Kraak (2004) beweer ook dat die vraag na gekwalifiseerde beroepslui met tegniese vaardighede die aanbod ver oorskry. Ek het ook daarna verwys dat 'n reuseagterstand in terme van tegnies opgeleide beroepslui ervaar word en dat vaardigheidstekorte in feitlik elke sektor van die ekonomie toeneem (Maree 2012a). Dit is kommerwekkend dat die situasie oor die afgelope aantal jaar nie betekenisvol verbeter het nie en dat daar tewens aanduidings is dat dit gaandeweg aan't verswak is. Geen land kan immers ekonomies toereikend groei nie, tensy daar genoeg tegnies opgeleide beroepslui gelewer word. Hierdie probleem is egter nie beperk tot Suid-Afrika nie. 'n Oorsig van waar die grootste beroepstekorte lê (ManpowerGroup 2013), toon die moeilikste, enkele beroepskategorie om te vul die afgelope 5 jaar is steeds die kategorie 'geskoolde vakmanne', gevolg deur die kategorie 'ingenieurs'. Hierdie aspek impakteer negatief op die land se wêreldwye mededingendheid en verlaag produktiwiteit oor die algemeen. Dit is kennelik essensieel dat hierdie saak indringend aandag vereis.

\section{Die verskynsel dat talle leerders enersyds met aandagafleibaarheid in een of ander vorm presenteer, en andersyds oor bogemiddelde tegniese belangstelling en aanleg beskik}

Afgesien daarvan dat dit noodsaaklik is dat daar genoeg toepaslik opgeleide onderwysers in Suid-Afrikaanse klaskamers is vir wiskunde en die fisiese wetenskappe (wat 
oor voldoende vakkennis- en vakonderrigkennis beskik), is dit ook van kritieke belang dat leerders wat oor ' $n$ bepaalde mate van aanleg en belangstelling in tegniese studierigtings beskik, tydig en toepaslik beroepsvoorligting moet ontvang. Laasgenoemde sluit advies in om hulle te help besluit of hulle wel in hierdie rigtings behoort te studeer, asook watter vlak van opleiding hulle kan oorweeg (aan 'n universiteit, 'n universiteit van tegnologie, 'n kollege vir verdere onderwys en opleiding [VOO-kollege] of ' $n$ privaat opleidingsinstansie [Maree 2010]).

Daar is pas weer bevind (Bilbao-Osorio, Dutta \& Lanvin 2014) dat Suid-Afrikaanse leerders besonder sterk afsteek in internasionale maatstafevaluerings ('benchmark evaluations') in, onder meer, wiskunde en die fisiese wetenskappe. In talle radioprogramme en koerantnavrae oor die onderwerp het ek dit gestel dat die volgende redes aangevoer word vir die ontstellende situasie:

- Die algemene swak opleiding van talle onderwysers in wiskunde en fisiese wetenskappe, by uitstek in plattelandse en township-skole.

- Die gebrek aan toepaslike onderrigmateriaal en leermateriaal in hierdie skole.

- Die algemene swak sosio-ekonomiese omstandighede in die meeste van hierdie omgewings, wat meebring dat talle ouers soms lang ure ver weg van hul huise werk en dus nie toepaslike steun aan hul kinders kan verleen nie.

- Die gebrekkige motivering onder en opleiding van talle onderwysers.

- Die skreiende gebrek aan toepaslike beroepsvoorligting in bykans al hierdie skole.

Ek het ook daarop gewys dat ek as navorser en opvoedkundige sielkundige oor die afgelope aantal jare 'n betekenisvolle toename gesien het in die aantal leerders wat enersyds met aandagafleibaarheid in een of ander vorm presenteer en andersyds oor bogemiddelde tegniese belangstelling en aanleg beskik. Ek het begin wonder of daar enige verband tussen die twee aspekte bestaan. Ek het wyd gesoek, maar kon geen navorsing in hierdie verband opspoor nie. Daar is al baie geskryf oor die uitdagings wat leerders met aandagafleibaarheid ervaar, maar niks is geskryf oor die spesifieke, idiosinkratiese uitdagings van aandagafleibare leerders met tegniese belangstelling en aanleg nie. In my ervaring is sulke leerders uitermate afhanklik van die hulp van ouers en ander betekenisvolle persone in hul lewens.

Ondanks die verskillende maniere waarop onderwysdepartemente die behoeftes van leerders met hierdie besondere uitdagings akkommodeer, geskied hulpverlening nie op 'n sistematiese en billike wyse aan alle betrokkenes nie.

\section{Aandagtekort(hiperaktiwiteit) versteuring}

Albertyn (2011) stel dit dat AT(H)V gekenmerk word deur aandagafleibaarheid, hiperaktiwiteit en impulsiwiteit. Sy stel dit egter duidelik dat $\mathrm{AT}(\mathrm{H}) \mathrm{V}$ nié die volgende is nie:
- kinders of adolessente wat hulle swak gedra of wangedra

- die resultaat van te veel suiker en preserveermiddels

- blote 'lewendigheid' of oordrewe opgewondenheid

- 'n nuwe soort 'gier-' (faddish) diagnose

- nie werklik 'n ernstige gebrek nie

- iets wat die kind sal ontgroei

- iets wat sonder medikasie bestuur kan word.

Intervensie om die uitdaging van $\mathrm{AT}(\mathrm{H}) \mathrm{V}$ te bestuur behoort geïntegreerd op vier fronte plaas te vind, naamlik:

- medies (die gebruik van medikasie)

- opvoedkundig (opvoedingverwante intervensie, insluitend die toepaslike opleiding van leerkragte om die uitdaging te hanteer)

- voorligting aan ouers, maar ook aan die leerder

- bestuur van die leerder se tuiskonteks (Deneckla 1996; Faraone \& Doyle 2001; Goldstein \& Ellis 2002).

\section{Teoretiese en konseptuele raamwerk vir die interpretasie van data: Beroepskonstruksieteorie en Lewenskonstruksieteorie}

Beroepskonstruksieteorie (BKT) (Savickas 2005) en Lewenskonstruksieteorie (LKT) (Guichard, in druk) dien as die teoretiese grondslag vir die onderhawige studie. Kortliks gestel, impliseer BKT en LKT dat individue beroepe kies en lewens ontwerp deur betekenis uit beroepservarings en lewenservarings te put. Die ontleding van hul response op hierdie ervarings ('n subjektiewe gebeure), bevorder begrip en insigverwerwing.

BKT is 'n oorkoepelende teorie gebaseer op drie klassieke teoretiese perspektiewe ten aansien van beroepsverwante gedrag, te wete die differensiële (persoon-omgewingpassing-), die ontwikkelingsmatige (lewenspan-, lewensruimte-), asook die dinamiese (storie- of narratiewe) perspektiewe (Hartung 2011; Savickas 2007). LKT is eweneens 'n oorkoepelende teorie gebaseer op drie klassieke, teoretiese perspektiewe, naamlik die sosiologiese, kognitiewe, asook dinamiese perspektiewe (Guichard 2009).

Die bevordering van refleksiwiteit, oftewel selfrefleksie ten aansien van 'n toetsling se beroep, lewe en ware gebeurtenisse (objektiewe ervarings), sowel as die betekenis wat geheg word aan sodanige gebeure (subjektiewe ervarings), onderlê beide BKT en LKT. Volgens BKT en LKT konstrueer mense hul loopbane en lewens omdat hulle betekenis heg aan hul eie gedrag (Guichard 2005; Savickas 2005) en hulself wil toerus met die aanpasbaarheidsvaardighede ('adaptive skills') wat nodig is sodat hulle die talle veranderings kan hanteer wat deur die veranderende wêreld van werk meegebring word. Persoonlike betekenis vervang dus die koesterende omgewing wat voorheen deur organisasies verskaf is. Individue se persoonlike identiteite verskaf die gom wat hul beroepstories en lewenstories bind en verskaf 'n biografiese brug wat hulle in staat stel om van een werksopdrag na 'n volgende aan te beweeg. 
Die lewensontwerpbenadering tot beroepsvoorligtingsintervensie is daarop gemik om individue te help om lewens te ontwerp en beroepe te konstrueer in die postmoderne inligtings- en kommunikasietegnologie-gemeenskappe (Savickas et al. 2009). Hierdie teoretiese raamwerk word beskou as die eerste ware beroepsvoorligtingsteorie nog (Maree 2013; Savickas 2013). Dit verenig ander teoretiese benaderings en vervang terme soos loopbaanvoorligting en beroepsopvoeding: 'They are supplementing the vocational guidance of modernity and the career education of high modernity with the career counseling of postmodernity' (Savickas 2011:9).

Die strewe na beroepsaanpasbaarheid, 'n essensiële en onontbeerlike lewensvaardigheid in die 21ste eeu, is 'n vername doelwit van beroeps- en lewenskonstruksie. Dit impliseer dat leerders bereid moet wees en toegang moet hê tot die nodige hulpbronne om kruispaaie en reuse veranderings in hul lewens en beroepe te bestuur, asook balans in hul lewens te handhaaf (Hartung 2011; Savickas 2011; Subich 2011). 'n Gekombineerde benadering tot beroepsvoorligting bied aan voorligters die beste kans om hierdie doel te verwesenlik.

\section{Doelstellings van die studie}

Die doel met die studie was om die unieke storie van 'n aandagafleibare leerder met tegniese belangstelling en aanleg te bekom en te ontleed. My uiteindelike doel was om die waarde van 'n geïntegreerde kwalitatiewe en kwantitatiewe benadering vir die beroepskonstruksie van die leerder te bepaal. Ek het veral gesoek na antwoorde op die volgende vrae:

- Watter veranderinge het daar ingetree tussen Graad 7 en Graad 9 ten opsigte van die 'beroepstorie' van 'n aandagafleibare leerder met tegniese belangstelling en aanleg?

- In watter mate kan 'n geïntegreerde kwalitatiewe en kwantitatiewe benadering tot beroepskonstruksie bydra tot die hantering van die idiosinkratiese uitdagings wat ervaar word deur' $n$ aandagafleibare leerder met tegniese belangstelling en aanleg?

'n Gevalstudie-benadering gebaseer op 'n kwalitatiewe, interpretatiewe paradigma kan moontlik lig werp op die vrae hierbo gestel. Dit kan dalk aandui of die beroepskonstruksie-benadering tot beroepsvoorligting in minstens een geval van hierdie aard suksesvol aangewend kan word.

\section{Metodes en tegnieke Paradigmatiese perspektief}

'n Geïntegreerde kwalitatiewe, interpretivistiese navorsingsparadigma is in die onderhawige studie geïnkorporeer. Die doel hiervan was om die deelnemer te bemagtig om self sin en betekenis te heg aan en te neem uit die beroepskonstruksiegebeure (weliswaar met begeleiding deur 'n beroepsvoorligter). Sodoende sou hy homself toepaslik kon adviseer betreffende besluite wat sy toekoms ten diepste raak.

\section{Idiografiese gevalstudie as navorsingsontwerp}

Die huidige studie kan beskryf word as 'n longitudinale, interpretatiewe, instrumentele en intrinsieke gevalstudie (Gordin 2006). Met intrinsiek bedoel ek dat ek waarlik geïnteresseerd is in die betrokke onderwerp en my ten doel stel om die 'geval' (deelnemer) beter te verstaan op grond van 'n spesifieke eienskap (prakties tegnies aangelê en presenterend met aandagafleibaarheid) (Baxter \& Jack 2008). Die belangstelling in die onderhawige gevalstudie spruit uit die feit dat ek al so dikwels oor die afgelope 30 jaar die betrokke verskynsel waargeneem het, maar geen navorsingsresultate oor die spesifieke onderwerp kon opspoor nie. Met instrumenteel bedoel ek dat my studie intervensie beoog waartydens 'n narratiewe of verhalende benadering gevolg sal word in ' $n$ poging om verandering in die deelnemer te probeer bewerkstellig. Afgesien daarvan dat ek die deelnemer grondig bestudeer het, is die betrokke intervensie en die invloed daarvan ook nagevors. Die deelnemer is instrumenteel wat betref die moontlike invloed van die verhalende benadering op sy selfbesef. Die ontledingseenheid (in hierdie geval die deelnemer) is 'n kritieke faktor in die verwerwing van geheelperspektief en -insig rakende die fenomeen wat ondersoek word (Nieuwenhuis 2010).

Tydreeksnavorsing (dit was 'n longitudinale studie) is gedoen om oor 'n tweejaarperiode inligting te versamel oor die deelnemer om die teenwoordigheid van hetsy verandering of vastigheid (bestendigheid) by die deelnemer waar te neem (Neuman 2000). Kwalitatiewe sowel as kwantitatiewe tegnieke is aangewend om die deelnemer se selfkonstruksie oor 'n bepaalde tydperk na te speur ('trace'). In plaas daarvan dat ' $n$ hipotese getoets is, het nuwe insigte telkens tydens die proses na vore getree en is dit ontleed.

\section{Deelnemer en agtergrond}

Gerieflikheidsteekproefneming en doelsteekproefneming is gebruik om 'n deelnemer te selekteer. 'n Vyftienjarige leerder (uit 'n gemiddelde sosio-ekonomiese omgewing) is in 2012 en weer in 2014 geselekteer op grond van sy tegniese belangstelling en aanleg, die feit dat hy met aandagafleibaarheid gepresenteer het, asook sy begeerte om in ' $n$ tegniese rigting te studeer. Hy is die jongste van drie kinders uit ' $n$ volledige gesin.

\section{Prosedure}

Twee assesseringsessies met die oog op beroepsvoorligting (in 2012 en weer in 2014) het plaasgevind. Die eerste sessie (aanvangsonderhoud, voltooiing van alle toetse en vraelyste, asook terugvoergesprek) het ongeveer ses en 'n half ure geduur, en die tweede was omtrent sewe ure lank.

Tydens die eerste fase van die assessering is die toetse afgeneem (kwantitatiewe assessering), narratiewe tegnieke toegepas (kwalitatiewe assessering) en die uitslae geïntegreer. Met ander woorde, vrae is gestel aan Johan ('n skuilnaam om die deelnemer se identiteit te beskerm) wat 
hom gelei het om oor fasette van sy lewe te reflekteer en in dié proses sy beroepslewensverhaal te ontlok (Savickas 2011). Nadat Johan en ek mekaar beter leer ken het, is die tweede fase aan 'magtiging' gewy: Johan is genooi om die beroepstorie ('assesseringsverslag') se waarde te bepaal (dus, sy beroepslewensverhaal te bekragtig) (Maree 2013). Die derde fase is uitgewys as die 'aksie'fase. Johan is uitgenooi om die aanbevelings wat tydens fase twee bespreek is, daadwerklik en aktief te ondersoek. Die beroepskonstruksieproses is uiteengesit. Johan se beroepslewensverhaal is in heroënskou geneem en aandag is aan moontlike toekomsplanne gegee. In 'n neutedop die hele intervensieproses was daarop gerig om Johan aan die gang te kry (beweging te fasiliteer [bv. om moontlike studierigtings te ontleed]) ten einde aktiewe selfkonstruksie (verbetering van sy selfbeeld, selfkonsep, en selfbesef), asook beroepskonstruksie (o.a. die kies van 'n studierigting en uiteindelik 'n loopbaan) te fasiliteer (Savickas 2011).

Ten einde wankommunikasie te vermy, is alle interpretasie van besprekings met Johan geverifieer.

\section{Etiek}

Maatreëls om Johan se welstand te verseker is deurgaans geïmplementeer. Ingeligte toestemming is van Johan en sy ouers verkry, en vertroulikheid is streng gehandhaaf. Terugvoer is tydens alle fases van die ondersoek aan Johan verskaf en die navorsingsbevindings is op beleefde wyse gerapporteer met die nodige verduideliking van begrippe wat hy aanvanklik nie verstaan het nie.

\section{Psigometriese instrumente}

Kwalitatiewe en kwantitatiewe inligting is versamel deur 'n data-insamelingsplan wat van verskillende metodes gebruik gemaak het. Die volgende psigometriese toetse is tydens die deelnemer se Graad 9-jaar in die studie gebruik: die Opname van Studiegewoontes en -houdings (OSGH) (Brown \& Holtzman 1974); die Jung-Persoonlikheidsvraelys (JPV) (Du Toit 1995); die Suid-Afrikaanse Beroepsbelangstellingsvraelys (SABBV) (Du Toit 1992); die RothwellMiller-belangstellingsvraelys (RMBV) (Hall, Halstead \& Taylor 1986); asook die Differensiële Aanlegtoetse - Vorm S (DAT-S) (Vosloo, Coetzee \& Claassen 2000).

Tydens sy Graad 11-jaar het Johan die volgende toetse voltooi: Die OSGH (Brown \& Holtzman 1974); die MyersBriggs Type Indicator (MBTI) (Martin 1995); die SABBV (Du Toit 1992); die RMBV (Hall, Halstead \& Taylor 1986); die Maree Career Matrix (MCM [Afrikaanse weergawe]) (Maree 2014); asook die Differensiële Aanlegtoetse (SAT-L) (Owen 2000). Alle toetse is in Suid-Afrika gestandaardiseer en bevredigende psigometriese eienskappe is gerapporteer. Die toetse is anoniem gemerk deur 'n onafhanklike persoon.

\section{Kwalitatiewe tegnieke}

Die Beroepsbelangstellingsprofiel (BBP) (Maree 2012c), sy narratiewe aanvulling, asook die lewensverhaaltegniek
(Cochran 1997), asook die Beroepskonstruksie-onderhoud (Hartung 2010; Savickas 2009) is gebruik. 'n Waardeprofiel is verkry deur informele vraelyste en gesprekke met die leerling. Hierbenewens is kwalitatiewe data ingesamel deur middel van semigestruktureerde onderhoude met en waarneming van Johan. Informele, semiformele en gerigte gespreksvoering het deurentyd plaasgevind met die oog daarop om die verhouding tussen myself en Johan bestendig te maak. Johan is boonop deurgaans geobserveer en aantekeninge is van alle observasies gemaak.

\section{Rol van die navorser}

Benewens my rol as navorser, het ek in die assesseringskonteks ook die rolle van fasiliteerder, instrument en vertroueling aangeneem.

\section{Ontleding en vertolking van data}

Kwantitatiewe resultate is gerapporteer en die betekenis daarvan is aan Johan verduidelik. Kwalitatiewe data is deurgaans ontleed. Johan is deurentyd versoek om onduidelikhede op te klaar, om te bevestig of ek hom reg verstaan en om die 'dieper' betekenis van sy antwoorde te verduidelik. Hy is voortdurend begelei om herhaaldelik te reflekteer oor sy refleksies, self na patrone in sy antwoorde te soek, verbande tussen konsepte te lê en om temas en subtemas in sy antwoorde te probeer vind. Kwalitatiewe en kwantitatiewe data is geïntegreer ten einde 'n holistiese of geheeloorsig te verkry. Ek het uiters omsigtig te werk gegaan om seker te maak dat Johan na homself luister en nie die foutiewe indruk kry dat ek die 'alleenekspert' (Savickas 1993) oor hom probeer wees nie. Dit sou die hele oefening verdag en tewens ietwat bespotlik maak.

\section{Resultate}

\section{Algemene agtergrond}

Beide Johan se ouers beoefen heeltydse beroepe. Daar is geen duidelike beroepstendense in die gesin nie. Johan is die jongste van drie kinders in 'n volledige gesin. Hy het 'n geskiedenis van aandagafleibare gedrag en is voorheen met $\mathrm{AT}(\mathrm{H}) \mathrm{V}$ gediagnoseer.

(Ter wille van bondigheid word slegs die Graad 11-uitslae vollediger verskaf. Waar laasgenoemde resultate van die Graad 9-uitslae verskil, word die ooreenstemmende Graad 9-uitslae tussen hakies verskaf.)

\section{Kwantitatiewe assessering}

Skoolpunte aan die einde van die eerste kwartaal in Graad 11 was soos volg:

- Afrikaans $64 \%$

- Engels 63\%

- Wiskunde $38 \%$

- Fisiese Wetenskappe $42 \%$

- Rekenaartoepassingstegnologie $44 \%$

- Ingenieursgrafika en -ontwerp $45 \%$

- Lewensoriëntering 92\%. 
Met die uitsondering van Lewensoriëntering, was sy punte in alle vakke onder die klasgemiddeld, maar vergelykenderwys marginaal beter as in Graad 9.

\section{Aanlegprofiel}

Die aanlegtoetse (SAT-L) het aangedui dat Johan oor die algemeen oor gemiddelde aanlegte beskik. Kwalitatiewe analise van sy antwoorde het egter aan die lig gebring dat hy nie daarin kon slaag om enige van sy nie-verbale subtoetse te voltooi nie.

\section{Studie-oriëntasieprofiel}

Die uitslag van die OSGH het aangedui dat Johan se studieoriëntasie sedert die vorige assessering aansienlik verbeter het. Hy is dan ook deur onderwysers en sy ouers beskryf as ' $n$ harde werker. Volgens hulle kon hy egter steeds heelwat harder werk, het hy nog by tye gesukkel om te fokus, konsentrasieprobleme ervaar, leeswerk en skryfwerk afgewys, en die afhandeling van skriftelike opdragte uitgestel. Hy kon sy program baie beter beplan en was agtelosig en rusteloos (het nie graag lank stilgesit om te leer nie). Sy stadige leestempo en werktempo en aandagafleibaarheid het by uitstek aandag verdien.

\section{Belangstellingsprofiel}

Die uitslae van die SABBV, die RMBV, asook die MCM het aangedui dat voorkeurbelangstellingsvelde ten tye van assessering in die prakties tegniese, bestuurs-, skeppende of musiek-, avontuur-, asook wetstoepassingsen regsverwante velde gesetel was (Graad 9: die prakties meganiese, sport- of buitelug- of avontuurverwante, musiekverwante, asook regsverwante velde).

\section{Persoonlikheidsprofiel}

Die Myers-Briggs Type Indicator (MBTI-tipe: EWDB) het aangedui dat Johan 'n ekstrovert was (Graad 9: introvert). Mense met sy persoonstipe is gewoonlik logies, beslis, sistematies, betroubaar, realisties en plat op die aarde; beskik gewoonlik oor leierseienskappe, asook oor natuurlike entrepreneursvaardighede en besluitnemingsvaardighede; verkies dat dit wat hulle doen praktiese toepassingswaarde het; funksioneer ten beste in 'n gestruktureerde en georganiseerde werksomgewing, ontwikkel gewoonlik tot 'n puik bestuurder en organiseerder, stig graag netwerke, gee graag leiding en is resultaatgeoriënteerd.

\section{Kwalitatiewe assessering}

Volgens die Beroepsbelangstellingsvraelys (BBV) was Johan se voorkeurbelangstellingsvelde soos volg:

- Ingenieurswese en die bou-omgewing (stem ooreen met sy voorkeur vir 'realisties' op die SABBV, 'meganies' op die RMBV).

- Regspraktyk en beskermingsdienste (sterk ooreenstemming met sy voorkeur vir 'wetstoepassing' op die SABBV; 'oorredend' op die RMBV, asook 'regspraktyk en beskermingsdienste' op die MCM).
- Musikaal (sterk ooreenstemming met sy voorkeur vir 'vermaak' op die SABBV).

- Prakties tegnies (sterk ooreenstemming met sy voorkeur vir 'werk met masjinerie' op die SABBV, prakties op die RMBV en prakties tegnies op die MCM).

- Avontuur, plante, diere en die omgewing (sterk ooreenstemming met sy voorkeur vir 'realisties' op die SABBV, meganies op die RMBV).

Die kwalitatiewe resultate het feitlik geensins verander vanaf Graad 9 na 11 nie, terwyl die kwantitatiewe resultate etlike veranderinge getoon het. Sy antwoorde op enkele vrae in die BBV se Narratiewe Byvoegsel (Maree 1986; Maree 2012c) verskyn hier onder. Geringe redigering is gedoen ten einde growwe taalfoute uit te skakel.

\section{Afdeling A}

Hoe kan ek vir jou van nut of waarde wees terwyl jy jou loopbaan beplan en ontwerp?

Help my om myself beter te verstaan en te ken, om uit te vind wat is my belangstellings, om sekerheid te kry oor wat ek 'moet' gaan doen. Wat sê die toetse, wat 'moet' ek gaan doen?

(Johan is taktvol, maar ferm daarop gewys dat niemand anders hom ooit so goed soos hyself sal ken nie, dat niemand vir hom kan sê wat hy 'moet' doen nie en dat slegs hy homself in sulke sake kan en mag adviseer. Hy is meegedeel dat hoewel ander wel inligting aan hom mag verskaf, die uiteindelike (verantwoordelikheid vir die) keuse van 'n beroep en studierigting syne en syne alleen is.)

\section{Afdeling B}

Ek sal jou graag beter wil leer ken. Voltooi asseblief die volgende stellings in die eerste persoon:

1. My (a) sterk punte, en (b) swak punte is

a. ek is liefdevol, betroubaar, behulpsaam, aanpasbaar, meganies aangelê en ek kan dinge goed ontleed

b. ek is nie sportief nie, hou nie daarvan as ek iets sê en mense trek my woord in twyfel nie of betwyfel my vermoë nie, en ek hou nie van kompetisie nie.

2. Ander mense sien my as iemand wat stres, maar darem nie te veel nie, wat baie redeneer oor dinge, wat probeer om sy rakke netjies te hou.

4. Wat ek as van die grootste waarde beskou, is akademiese prestasie, Christelike beginsels, goeie menseverhoudinge, om ander te help.

6. Toe ek nog baie jonk was, het ek die volgende drie persone bewonder:

Steve Hofmeyr: Alhoewel hy swaar grootgeword het, het hy nie opgegee nie.

Juanita du Plessis: Sy het toegewyd haar sangdroom nagejaag.

'n Bekende politikus: Hy was nie bang om op te staan vir wat reg en wat verkeerd was nie.

(Die beweegrede vir hierdie vraag is dat dit lig werp op die toetsling se selfkonsep, sentrale lewenstemas, asook 
oplossings vir sy sentrale lewensprobleme [Savickas 2011].)

8. My drie gunstelingleuses of -aanhalings:

Neem die goeie uit die verlede en bou jou toekoms daarop; nie op die negatiewe nie.

Bly altyd en in alle omstandighede positief, al gaan dit swaar.

Moenie opgee nie.

Staan saam; so bereik 'n mens meer.

(Die beweegrede vir hierdie vraag is dat dit lig werp op die toetsling se raad aan hom- of haarself.)

9. My (a) gunstelingtydskrif, (b) -TV-program, en (c) -webtuiste en waarom:

a. SA $4 \times 4$ omdat ek hou van motors en meganiese dinge.

b. Bowhunter of Jag of Landbouweekblad omdat ek baie lief is vir die natuur en vir avontuur.

c. Stuff omdat dit handel oor tegnologie.

(Die beweegrede vir hierdie vraag is dat dit lig werp op toetslinge se belangstellings, die omgewings wat pas by hul verkose lewenstyl en die omgewing waarbinne hulle hulleself wil uitleef.)

11. My gunstelingboek: Mr Bean

Die hoofkarakter in hierdie boek is $M r$ Bean. Sy verstrooidheid en aandagafleibaarheid was sy grootste uitdagings. Hy het dit gehanteer deur maar daaroor te lag en altyd die beste te probeer maak van 'n slegte saak. (Die beweegrede vir hierdie vraag is dat dit lig werp op karakters wat dieselfde uitdaging[s] as die toetsling ervaar [het] en aandui hoe die karakter te werk gegaan het om die uitdagings te hanteer.)

14. My drie grootste uitdagings ('probleme') toe ek nog jonk was, was:

Om te konsentreer, om deur te kom, om selfstandig te wees en nie altyd vir ander om hulp te vra met klein goedjies nie, asook om my nie soveel te bekommer oor wat ander van my sê of dink nie.

15. My drie vroegste herinnerings (stories oor dinge wat ek kan onthou wat met my gebeur het toe ek nog baie jonk was): Ter wille van bondigheid, word slegs die titels (waarin die hooftemas dus vervat is) hier weergegee:

a. Argeloosheid bring onnodige pyn en ontwrigting mee.

b. Selfs erge pyn kan oorskry word deur uithouvermoë.

c. Leef verby pynlike en onredelike sienings en optrede.

Volgens Hartung (2010) en Maree (2013) onthul of verklap die eerste vroeë herinnering toetslinge se diepliggendste beroepslewenstema. Die tweede een verskaf gewoonlik hul advies aan hulleself rakende moontlike wyses waarop hierdie uitdaging gehanteer kon word (of borduur soms hierop voort). Die derde herinnering bevestig die toetslinge se advies aan hulleself oor moontlike maniere om die uitdaging te hanteer.

\section{Waardes}

Johan wil graag presteer op akademiese vlak, koester interpersoonlike verhoudinge, is sterk ingestel op Christelike waardes en wil vir ander iets beteken. (Hoewel hy in Graad 9 dieselfde waardes geverbaliseer het, het sy Graad 11-resultate gedui op 'n sterker bereidwilligheid om te werk aan die realisering van hierdie waardes.)

\section{Selfsiening}

Johan se selfbeeld, selfkonsep, asook selfbesef is kennelik toereikend. Hy besef toenemend dat hy alles in sy vermoë sal moet doen om sy drome te verwesenlik, homself toereikend te konstrueer, te kwalifiseer vir verdere studie in sy gekose studieveld, asook 'n gelukkige lewe te ontwerp en betekenisvolle maatskaplike bydraes te maak. Johan verklaar dat 'n onderwyser enkele jare gelede aan hom gesê het dat hy nie oor die potensiaal beskik om Graad 12 te slaag nie en dat hy uitermate daarop ingestel is om hierdie persoon se negatiewe voorspelling verkeerd te bewys.

\section{Aanbevelings}

Die kwalitatiewe uitslae is eerste bespreek ten einde Johan te help om sentrale lewenstemas te identifiseer (kristallisasie is bewerkstellig [Teddlie \& Tashakkori 2009]), waarna die kwantitatiewe uitslae bespreek is. Hierna is enkele aanbevelings gemaak rakende moontlike studierigtings wat verken kon word, asook psigososiale vaardighede wat Johan sou kon bemeester ten einde hom te help om homself toereikend te konstrueer (voorheen is hierna verwys as optimale selfaktualisering [Maslow 1987]). Johan moes deurgaans reflekteer oor die verband tussen die kwalitatiewe en kwantitatiewe uitslae (triangulasie is bewerkstellig). Johan het saam met my die lysie hier onder opgestel van moontlike studievelde wat hy sou kon ontleed om hom in staat te stel om 'n ingeligte studiekeuse en beroepskeuse te maak.

\section{Tersiêre opleiding Universiteitsvlak}

Die volgende studierigtings aan 'n universiteit is aanbeveel vir verdere verkenning. Johan is egter daarop gewys dat sy huidige toelatingspunt-telling waarskynlik nie goed genoeg was om toelating te fasiliteer nie:

- BEd Senior en Verdere Onderwys- en Opleidingsfase (Meganiese of Siviele Tegnologie of Ingenieursgrafika en Ontwerp).

\section{Universiteit van Tegnologie}

- Konstruksiebestuur.

- Stads- en Streeksbeplanning.

- Polisiëring.

Opleidingsinstansies met 'n tegniese inslag of Kolleges vir Verdere Opleiding en Onderrig is ook vermeld. Studierigtings alhier wat verken kon word, was:

- Meganiese ingenieurswese.

- Megatronika of Boukonstruksie.

Johan is ook aangeraai om die moontlikheid te verken om 'n leerderskap ('Learnership') in (bv.) Boukonstruksie, Elektrisiënswerk of Megatronika te voltooi. Hy is aangeraai om navraag te doen oor ' $n$ moontlike werkgewer en om ook die relevante SETA in hierdie verband te nader. 


\section{Fasilitering van beweging}

Soos reeds gestel, behels die derde fase van hedendaagse beroepsvoorligting die fasilitering van beweging deur die toetsling (Maree 2013; Savickas 2011). Om Johan te help om ' $n$ ingeligte besluit te neem, is hy dus aangeraai om deeglike werksontleding doen. Dit sou werkskadu ('work shadowing'), vakansiewerk, vrywillige werk, gesprekvoering met beroepsbeoefenaars, werkgewers en werknemers, besoeke aan opleidingsinstansies, bywoning van opedae en mini-opedae en die bestudering van sowel gedrukte as internetgebaseerde brosjures, inligtingstukke en ander kommunikasiestukke kon insluit. (Johan is byvoorbeeld verwys na careerexpo.co.za, www.careers.co.za, http:// www.careerjunction.co.za/, http: / / www.pacecareers. com/, pace.www.gostudy.mobi, asook http://www.nqf. org.za/.) Hy is aangeraai om eers ná afloop hiervan sy finale beroepskeuse uit te oefen.

Johan is ernstig daarop gewys dat voorgenoemde studierigtings in geen bepaalde voorkeurorde gerangskik is nie, maar wel gerieflikheidshalwe in enkele breë beroepskategorieë georden is. Hy is verder daaraan herinner dat die verantwoordelikheid om 'n beroepskeuse te maak, sy eie verantwoordelikheid is en dat niemand so ' $n$ belangrike besluit namens 'n ander mag neem nie. Verder is sy aandag daarop gevestig dat die maak van 'n beroepskeuse deesdae veel ingewikkelder is as die blote lineêre, eenmalige keuse van 'n beroep vir die res van 'n mens se lewe.

Johan is voorts daarop attent gemaak dat hy etlike van sy belangstellings by wyse van stokperdjiebeoefening sou kon uitleef deur byvoorbeeld as student in die universiteitskoor te sing, sy eie musiekgroepie te stig of by 'n bestaande musiekgroep aan te sluit.

\section{Aanbevelings wat met studie-oriëntasie verband hou}

Johan is aangeraai om indringend aandag te gee aan daardie aspekte van sy studie-oriëntasie waarna elders in hierdie verslag verwys is en om te mik vir 'n gemiddeld van ongeveer $65 \%$ of hoër. Koöperatiewe kleingroepwerk (m.a.w. studie saam met 'n klein groepie gemotiveerde leerlinge) is sterk aanbeveel. Hierbenewens is hy aangeraai om gereeld vraestelle in gesimuleerde eksamenomstandighede af te lê en sy vraestelle te laat merk en 'ontleed'. Die belangrikheid daarvan om Johan se studieroetine en studieomgewing deeglik te organiseer en te struktureer is beklemtoon.

\section{Fasilitering van toereikender selfkonstruksie deur te let op die verwerwing van bepaalde psigososiale en ander vaardighede}

Johan is aangespoor om aan 'n beperkte getal goed geselekteerde skoolverwante aktiwiteite deel te neem en veral daarop te fokus om tydsbestuursvaardighede te probeer verwerf ten einde sy korttermyndoelwitte, mediumtermyndoelwitte en langtermyndoelwitte deeglik te konseptualiseer, uit te skryf en iewers in sy kamer aan te bring. Ekstra klasse in wiskunde en fisiese wetenskappe kon oorweeg word. Johan is aangeraai om baie meer te lees (insluitend boeke, tydskrifte, koerante). Johan se ouers is versoek om namens hom vir die dienste van 'n tutor of amanuensis aansoek te doen, asook vir ekstra tyd by die voltooiing van toetsvraestelle en eksamenvraestelle. Hulle is verder aangeraai om dit te oorweeg om hom vir'n neurologiese opvolg-evaluasie te neem na die neuroloog wat hy voorheen gekonsulteer het rakende die gebruik van medikasie soos Ritalin, Concerta of Strattera om sy konsentrasie te verbeter en sy aandagafleibaarheid teë te werk.

\section{Bespreking}

Soos hierbo verduidelik, het Johan se twee stelle belangstellingsprofiele (vanaf Graad 9 na Graad 11) stabiel voorgekom (Holland 1985). Die kwalitatiewe resultate was selfs meer stabiel as die kwantitatiewe resultate. Hierdie uitslag het boonop sterk positief gekorreleer met beroepsaanbevelings wat met die Myers-Briggs-resultate geassosieer word (in ooreenstemming met sy EWDBtipe). Dit het baie duidelik geblyk dat ' $n$ gestruktureerde omgewing vir Johan van kardinale belang was (in harmonie met sy B- tipe en W-tipe). Hy het geglo in sy vermoë en sy bereidwilligheid om homself te handhaaf, het ander se twyfel in en onderskatting van sy vermoëns oorskry (in ooreenstemming met sy E-tipe en D-tipe) (Martin 1995). Volgens die uitslae van die tegniek van die drie vroegste herinneringe was Johan terdeë bewus daarvan dat argeloosheid en agtelosigheid (aandagafleibaarheid) 'onnodige' ongerief, ongemak en hindernisse veroorsaak ('n sentrale lewenstema). Sy advies aan homself was om uithouvermoë aan die dag te lê, hard te werk, verby kortsigtige evaluerings van sy situasie te streef en op die positiewe aspekte daarvan te fokus. Hierdie resultate korreleer positief met sy E-tipe en veral met sy gewilligheid om voortdurend uitdagings te aanvaar. Sy aksentplasing op die positiewe kant van sy self, asook sy geesdrif om te presteer en sy gestelde beroepslewenstemas te bereik was deurlopend merkbaar (bevestig deur sy W-tipe).

Die volgende resultaat (na aanleiding van Johan se voltooiing van die MCM in Graad 11) verdien besondere vermelding. Ondanks sy lae punte, was Johan tydens die Graad 9-toetsingsgeleentheid vasbeslote om aan 'n universiteit in te skryf vir ingenieurswese. In Graad 11 het sy belangstelling en sy aanleg in of selfvertroue ten opsigte van die volgende twee beroepskategorieë onderskeidelik soos volg daar uitgesien.

Tabel 1 dui aan dat Johan se belangstelling in beide beroepskategorieë sterk is (10 en 12 uit 'n moontlike 16). Hy skat egter dat sy aanleg om in 'n prakties tegniese studierigting sukses te behaal (aan 'n universiteit van tegnologie, VOO-kollege of privaat opleidingsinstansie)

TABEL 1: Johan se geskatte belangstelling in en aanleg vir tegniese en ingenieursverwante studierigtings volgens die Maree Career Matrix.

\begin{tabular}{lll}
\hline Beroepskategorie & Belangstelling & Selfvertroue \\
\hline Prakties tegnies & 10 & 13 \\
Ingenieurswese en die bou-omgewing & 12 & 7 \\
\hline
\end{tabular}


aansienlik hoër is (13 uit 16) vergeleke met sy kans om aan 'n universiteit te slaag (7 uit 16). Hierdie resultaat, wat sterk positief korreleer met die aanlegresultate en dui op toepaslike, nuut verworwe insig in sy situasie, is myns insiens van wesenlike belang vir beroepsvoorligters op alle vlakke. Volgens Gati, Fishman-Nadav en Shiloh (2006), maar ook Harrington en Schafer (1996) verskaf toetslinge deur die skatting van hul vermoëns 'n sterk aanduiding van hul selfkonsep en selfbeeld. Savickas (1999) het ná intensiewe navorsing tot die gevolgtrekking gekom dat daar oorgenoeg bewys is om te aanvaar dat toetslinge se belangstellings sterk verband hou met hul geskatte vermoë om in bepaalde rigtings te presteer. Ook Donnay en Borgen (1999) en Tracey en Hopkins (2001) het gewys op die sterk positiewe ooreenkoms tussen selfskatting van aanleg vir bepaalde studierigtings en vaardighede enersyds, en belangstelling andersyds. Ek stem volmondig saam met Campbell, Hyne en Nilson (1992:39), wat reken dat '... self-perceptions about skills that is, an individual's beliefs about how well he or she can perform different occupational activities - already play an important role in career choices'. Tewens, my eie navorsing oor etlike dekades het afdoende bewys vir hierdie stelling verskaf.

\section{Die verhalende beroepsfasiliteringsproses as geheel}

Johan het die proses van gekombineerde beroepsvoorligting baie positief ervaar. Aan die einde van die sessie, toe ek sy aanvanklike antwoord op my vraag: Hoe kan ek vir jou van nut wees? aan hom voorgehou het en gevra het of die sessie vir hom nuttig was, het hy glimlaggend soos volg op die proses kommentaar gelewer:

Ek verstaan myself nou beter en is bly ek het by myself gehoor wat ek wil gaan doen! Ek is verlig dat ek aan my 'ander' belangstellings ook sal kan aandag gee want ek is byvoorbeeld baie lief vir my musiek. Dit was lekker om te hoor wat ek gesê het, soos u sê, na my eie raad te luister.

\section{Opvolgresultate}

\section{Vyf maande later}

Vyf maande ná die laaste evaluering het Johan 'n gemiddeld van ongeveer $59 \%$ in sy eksamen behaal. Die aanbevelings in sy Graad 11-verslag is noulettend uitgevoer en hy het gevoel dat hy in beheer is van sy skoolsituasie. Hy het gemoedsekerheid gehad rakende die bevinding dat universiteitstudie in ingenieurswese nie na 'n realistiese opsie gelyk het nie en was besig om werksontleding uit te voer. Johan is oor die algemene beskryf as 'n gelukkige, goed funksionerende jong man met ' $n$ realistiese selfbeeld en selfbesef.

\section{Aanbevelings: Raad aan diensdoende onderwysers}

Daar word eerstens aanbeveel dat sowel Lewensoriënteringonderwysers as 'ander' onderwysers kennis behoort te neem van die 'nuwe' benadering tot beroepsvoorligting. Om die waarheid te sê - elke onderwyser behoort in 'n sekere sin 'n beroepsvoorligter te word (Nzimande 2010).
Tweedens: Alle sielkundiges en onderwysers behoort daarop te let dat beroepsvoorligtingstoetse bepaald nie afdoende inligting lewer om beroepskeuses of sukses in studierigtings en in die beroepslewe self akkuraat te voorspel nie. 'n Geïntegreerde benadering bring egter hoogs waardevolle inligting voort aan die hand waarvan leerders self tot ingeligte besluite rakende hul studiekeuses en beroepskeuses kan kom.

Onderwysers behoort hulself derdens op hoogte te bring ten aansien van sake soos die volgende:

- Die wêreldwye tendens om op sowel meetbare as niemeetbare aspekte van leerders se persoonlikheid te fokus alvorens waarde- en ander oordele oor hulle gemaak word.

- Die belangrikheid daarvan om beskeie te wees oor wat ons werklik van ons leerders weet, en in dieselfde asem, om te aanvaar dat hulle veel meer van hulself weet as wat ons ooit sal kan weet of verstaan.

- Die belangrikheid daarvan om toetsuitslae nie op sigwaarde alleen te probeer interpreteer nie, maar om telkens te poog om resultate in konteks te plaas en te interpreteer.

- Insig daarin dat lewensukses deur 'n ingewikkelde, multidimensionele kombinasie van faktore bepaal word.

- Insig en die vermoë om leerders se talle ervarings te normaliseer, hulle aan te moedig en deurgaans te inspireer.

Elke poging denkbaar behoort vierdens aangewend te word om alle leerders te laat baat by nuwer benaderings in die veld van beroepsielkunde. Kwalitatiewe inligting in besonder kan en behoort deur elke onderwyser in elke klas ingesamel en aan belanghebbendes oorgedra te word.

Vyfdens behoort die gebruik van medikasie om aandagafleibaarheid te hanteer op nasionale vlak ondersoek te word. Daar word beweer dat groot getalle (selfs 50\% van alle leerders of studente) medikasie soos Ritalin, Concerta of Strattera gebruik (Swanepoel 2012). Afgesien van die etiek verbonde aan die gebruik van hierdie tipe medikasie sonder die nodige mediese ondersoeke vooraf, spreek dit vanself dat die meer vermoënde sektor van die samelewing hierdie 'kruk' sal kan gebruik, terwyl behoeftiger studente die 'luukse' nie sal kan bekostig nie.

Sesdens is dit essensieel dat konsensus bereik word oor wat presies sielkundiges, onderwysers en dosente verstaan onder die term $\mathrm{AT}(\mathrm{H}) \mathrm{V}$, dat toepaslike assesseringskriteria en assesseringsstrategieë ontwerp word om die fenomeneen en die omvang daarvan te assesseer. Hierna behoort navorsing op nasionale vlak aangevoer, beplan en uitgevoer te word rakende die omvang van $\mathrm{AT}(\mathrm{H}) \mathrm{V}$ in ons skole en universiteite. Bevindings behoort omgeskakel te word in praktiese, uitvoerbare aanbevelings. Sake soos die volgende behoort, onder andere, aandag te geniet:

- Wat is die presiese omvang van $\mathrm{AT}(\mathrm{H}) \mathrm{V}$ in ons skole en universiteite? 
- Wat is die verband tussen $\mathrm{AT}(\mathrm{H}) \mathrm{V}$ en prestasie in alle vakke, maar, uit die perspektief van die onderhawige artikel, veral dan ook tussen $\mathrm{AT}(\mathrm{H}) \mathrm{V}$ en prestasie van leerders wat belangstel in en aanleg toon vir tegniese vakke.

Die einddoel is eenvoudig: Om ' $n$ daadwerklike poging aan te wend om die uitdaging wat $\mathrm{AT}(\mathrm{H}) \mathrm{V}$ aan leerders stel, so doelmatig moontlik te hanteer. Gegewe die nasionale krisis (waarna vroeër in die huidige artikel verwys is), naamlik dat die vraag na gekwalifiseerde beroepslui met tegniese vaardighede die aanbod ver oorskry, asook die reuse-agterstand in terme van tegnies opgeleide beroepslui, verdien hierdie saak die aandag van elke regdenkende mens in hierdie land.

\section{Gevolgtrekking}

Opsommend kan genoem word dat 'n sterk positiewe korrelasie tussen die kwantitatiewe (positivistiese) en kwalitatiewe (verhalende) temas in die beroepsvoorligtingsituasie na vore getree het. Die waarde van 'n geïntegreerde benadering vir onderwys (soos in hierdie artikel bespreek) in Suid-Afrika en elders in die 21ste eeu spreek vanself. Hierdie benadering is sterk in ooreenstemming met die Departement van Basiese Onderwys se benadering tot die hantering van leerders wat leerhindernisse ('barriers to learning') ervaar, naamlik dat die klem moet verskuif vanaf die kategorie van gebrek na die vasstelling van die vlak en aard van ondersteuning. In plaas daarvan dat die uitdaging bloot kwantitatief geassesseer word, verskuif die aksent dus na 'n bestekopname van die leerder se sterk punte en idiosinkratiese behoeftes:

This is in line with the Convention on the Rights of the Child (1989) and the Convention on the Rights of person with Disabilities which advocate for putting 'the child first' instead of the disability. (Department of Basic Education [DBE] 2014:24)

In die onderhawige geval is dit veral belangrik om daarop te let dat die toetsling (wat potensieel 'n substansiële bydrae tot die nasionale ekonomie kan lewer) bepaald nie sonder die nodige opvoedkundige sielkundige, asook mediese steun en intervensie in staat sou wees om sy potensiaal toepaslik te verwesenlik nie. My navorsing dui daarop dat die aard van hierdie spesifieke uitdaging waarskynlik heeltemal onderskat word. Daar is myns insiens baie duisende ander leerders wat soortgelyke uitdagings as Johan ervaar en nie noodwendig slegs leerders met belangstelling en aanleg in tegniese rigtings nie. Hierdie leerders kan waarskynlik met die nodige steun hulself op 'n veel hoër vlak verwesenlik. Hulle kan substansieel verbeter op hul skolastiese prestasie en daarmee hul kans op keuring vir bepaalde studierigtings, hul studiesukses en beroepsukses, asook hul uiteindelike lewensgeluk en betekenisvolle maatskaplike bydraes grotendeels verhoog. In hierdie opsig sluit my navorsingsbevinding en -aanbeveling sterk aan by die sienings van Foucault (1975) en Wink (2005). Laasgenoemde argumenteer oortuigend ten gunste van 'n kritiese opvoedkunde (insluitend die bevraagtekening van 'verstokte' idees) wat uiteindelik 'n emansipatoriese funksie behoort uit te oefen (Isaacs, in druk). In die onderhawige geval is die implikasie: bevry leerders van die faktore wat inperkend en beperkend uitwerk op hul kans op beroepskonstruksie en lewenskonstruksie.

Die uitkomste in Johan se geval kan vanselfsprekend nie veralgemeen word nie. Intensiewe navorsing met groepe en in verskillende kontekste is essensieel voordat resultate algemeen toegepas kan word. Dit kan nietemin opsommend gestel word dat die benadering wat met hom gevolg is, potensieel waardevol kan wees vir miljoene ander leerders in diens van hul selfkonstruksie, die kies en beoefening van 'n suksesvolle beroep, die ontwerp van 'n gelukkige lewe en, eindelik, die maak van betekenisvolle maatskaplike bydraes.

\section{Erkenning}

Die deelnemer en sy ouers word bedank vir hul deelname aan die navorsing.

\section{Mededingende belange}

Die outeur verklaar hiermee dat hy geen finansiële of persoonlike verbintenis het met enige party wat hom voordelig of nadelig in die skryf van hierdie artikel kon beïnvloed nie.

\section{Literatuurverwysings}

Albertyn, L., 2011, 'Learning challenges in higher education: Implications and remedies', Keynote presentation at the Conference on Learning Disabilities and ADHD in Higher Education, Johannesburg, South Africa, October.

Baxter, P. \& Jack, S., 2008, 'Qualitative case study methodology: Study design and implementation for novice researchers', The Qualitative Report 13, 544-559.

Bilbao-Osorio, O., Dutta, S. \& Lanvin, B., 2014, The Global Information Technology Report 2014, World Economic Forum (WEF), Geneva, Switzerland.

Brown, W.F. \& Holtzman, W.H., 1974, Opname van studiegewoontes en -houdings (OSGH) Vorm H. RGN, Pretoria, Suid-Afrika.

Campbell, D.P., Hyne, S.A. \& Nilson, D.L., 1992, Manual for the Campbell interest and skill survey: CISS, National Computer Systems, Minneapolis, MN.

Cochran, L., 1997, Career counseling: A narrative approach, Sage, Thousand Oaks, CA.

Datum recruitment services, 2013, Top 10 jobs in South Africa, viewed 21 April 2014 from http://datum-recruitment.com/blog/2013/01/03/top-10-jobs-in-southafrica/

Deneckla, M.B., 1996, 'Measurement of executive functioning', in G.R. Lyon (ed.), Frames of reference for the assessment of learning disabilities: New views on measurement issues, pp. 117-142, Brookes, Baltimore, ML.

Department of Basic Education (DBE), 2014, Draft policy on screening, identification, assessment and support, Department of Basic Education, Pretoria, South Africa.

Donnay, D.A.C. \& Borgen, F.H., 1999, 'The incremental validity of vocational selfefficacy: An examination of interest, self-efficacy, and occupation, Journal of Counseling Psychology 46, 432-447. http://dx.doi.org/10.1037/0022-

Du Toit, L.B.H., 1995, Jung-Persoonlikheidsvraelys, RGN, Pretoria, Suid-Afrika.

Du Toit, R., 1992, Suid-Afrikaanse Beroepsbelangstellingsvraelys (SABBV), RGN, Pretoria, Suid-Afrika.

Faraone, S.V. \& Doyle, A.E., 2001, 'The nature and heritability of attention-deficit/ hyperactivity disorder', Child and Adolescent Psychiatric Clinics of North America 10, 299-316.

Foucault, M., 1975, Discipline and punish: The birth of the prison, Vintage Books, New York.

Gati, I., Fishman-Nadav, Y. \& Shiloh, S., 2006, 'The relations between preferences for using abilities, self-estimated abilities, and measured abilities among caree counseling clients', Journal of Vocational Behavior 68(1), 24-38. http://dx.doi. org/10.1016/j.jvb.2005.04.002

Goldstein, S. \& Ellis, A.T., 2002, Clinician's guide to adult ADHD: Assessment and interventions, Academic Press, Boston, MA.

Gordin, P.C., 2006, An instrumental case study of the phenomenon of collaboration in the process of improving community college developmental reading and writing instruction, viewed $21 \mathrm{April} 2014$, from http://scholarcommons.usf.edu/etd/2536

Guichard, J., 2005, 'Life-long self-construction', International Journal for Educational and Vocational Guidance 5, 111-124. http://dx.doi.org/10.1007/s10775-005$8789-\mathrm{y}$ 
Guichard, J., 2009, 'Self-constructing', Journal of Vocational Behavior 78(3), 251-258. http://dx.doi.org/10.1016/j.jvb.2009.03.004

Guichard, J., in press, 'From vocational guidance and career counselling to life design dialogues', in J. Rossier \& L. Nauta, (eds.), Handbook of the life design paradigm From practice to theory, from theory to practice, Hogrefe and Huber, Boston, MA

Hall, B.A., Halstead, M.E. \& Taylor, T.R., 1986, Rothwell-Miller-belangstellingsvraelys, RGN, Pretoria, Suid-Afrika.

Harrington, T.F. \& Schafer, W.D., 1996, 'A comparison of self-reported abilities and occupational ability patterns across occupations', Measurement and Evaluation in Counseling and Development 28, 180-190.

Hartung, P.J., 2010, 'Identifying life-career themes with the career-style questionnaire', in K. Maree (ed.), Career counselling: methods that work, pp. 161-168, Juta, Cape Town, South Africa.

Hartung, P.J., 2011, 'Career construction: Principles and practice', in K. Maree (ed.), Shaping the story: A guide to facilitating narrative counselling, pp. 103-119, Sense, Rotterdam, The Netherlands.

Holland, J.L., 1985, Making vocational choices: A theory of vocational personalities and work environments, Prentice Hall, Englewood Cliffs, N.J.

Isaacs, T., in press, 'Review of a guide to reflective career counseling by Prof. Kobus Maree', South African Journal of Higher Education 28.

Kraak, A., 2004, An overview of South African human resources development, HSRC Cape Town, South Africa.

Kraak, A., 2008, 'Three pathways to intermediate skilling', in A. Kraak \& K. Press (ed.), Human resource development review 2008: Education, employment and skills in South Africa, pp. 479-502, HSRC Press, Cape Town, South Africa.

Kraak, A., 2010, 'The collapse of the graduate labour market in South Africa: Evidence from recent studies', Research in Post-Compulsory Education 15(1), 81-102. http://dx.doi.org/10.1080/13596740903565384

ManpowerGroup, 2013, Talent Shortage Survey, viewed 21 April 2014, from http:// www.manpowergroup.com/wps/wcm/connect/manpowergroup-en/home/ thought-leadership/research-insights/talent-sources/

Maree, J.G., 1986, Career counselling: Individual workbook for students, University of Pretoria, Pretoria.

Maree, J.G., 2010, 'Critical appraisal of the system of education and prospects of meeting the manpower and developmental needs of South Africa', Africa Insight $40(2), 85-108$

Maree, J.G., 2012a, "n Voorlopige studie tot die waarde van 'n gekombineerde kwantitatiewe-kwalitatiewe benadering tot beroepsvoorligting met ' $n$ natuurwetenskapstudent: 'n Longitudinale gevalstudie', Suid-Afrikaanse Tydskrif vir Natuurwetenskap en Tegnologie 31(1), http://dx.doi.org/satnt.v31i1.383

Maree, J.G., 2012b, A guide to reflective career counselling [DVD], Jopie van Rooyen \& Partners, Randburg, South Africa.

Maree, J.G., 2012c, The Career Interest Profile (Version 4), Jopie van Rooyen \& Partners, Randburg, South Africa.

Maree, J.G., 2013, Counselling for career construction: Connecting life themes to construct life portraits. Turning pain into hope, Sense, Rotterdam, The Netherlands. http://dx.doi.org/10.1007/978-94-6209-272-3

Maree, J.G., 2014, Maree Career Matrix, Jopie van Rooyen \& Partners, Randburg, South Africa.

Martin, C.R., 1995, Looking at type and careers, Center for Applications of Psychological Type, Gainesville, FL.

Maslow, A.H., 1987, Motivation and personality, 2nd edn., Addison-Wesley, New York NY.
Neuman, L.W., 2000, Social research methods: Qualitative and quantitative approaches, 4th edn., Allyn and Bacon, Boston, MA.

Nieuwenhuis, J., 2010, 'Introducing qualitative research', in K. Maree (ed.), First steps in research, 2nd edn., pp. 47-68, Van Schaik, Pretoria, South Africa.

Nzimande, B., 2010, 'Teachers must be "skilled counsellors"', viewed 21 April, from http://www.news24.com/SouthAfrica/News/Teachers-must-be-skilledcounsellors-20100707

Owen, K., 2000, Manual for the Differential Aptitude Tests (SAT-L), HSRC, Pretoria, South Africa.

Savickas, M.L., 1993, 'Career counseling in the postmodern era', Journal of Cognitive Psychotherapy: An International Quarterly 7(3), 205-215.

Savickas, M.L., 1999, 'The psychology of interests', in M.L. Savickas \& A.R. Spokane (eds.), Vocational interests, pp. 19-56, Davies-Black, Palo Alto, CA.

Savickas, M.L., 2005, 'The theory and practice of career construction', in S.D. Brown \& R.W. Lent (eds.), Career development and counseling: Putting theory and research to work, pp. 232-245, John Wiley \& Sons, Hoboken, NJ.

Savickas, M.L., 2007, 'Prologue: Reshaping the story of career counselling', in K.Maree (ed.), Shaping the story: A guide to facilitating narrative counselling, pp. 1-3, Van Schaik, Pretoria, South Africa.

Savickas, M.L., 2008, 'Helping people choose jobs: A history of the guidance profession', in J.A. Athanasou \& R. van Esbroeck (eds.), International handbook of career guidance, pp. 97-113, Springer, London, England. http://dx.doi. org/10.1007/978-1-4020-6230-8 5

Savickas, M.L., 2009, The essentials of life design counselling, Invited public lecture, University of Pretoria, Pretoria, South Africa, April.

Savickas, M.L., 2010, Life designing: Framework and introduction, 27th International Congress of Applied Psychology, Melbourne, Australia, July.

Savickas, M.L., 2011, Career counseling, American Psychological Association, Washington, D.C.

Savickas, M.L., 2013, 'The theory and practice of career construction', in S.D. Brown \& R.W. Lent (eds.), Career development and counseling: Putting theory and research to work, 2nd edn., pp. 147-186, Wiley, Hoboken, NJ.

Savickas, M.L., Nota, L., Rossier, J., Dauwalder, J.-P., Duarte, M.E., Guichard, J. et al. 2009, 'Life designing: A paradigm for career construction in the $21^{\text {th }}$ century', Journal of Vocational Behavior 75, 239-250. http://dx.doi.org/10.1016/j. jvb.2009.04.004

Subich, L.M., 2011, 'Tracing the evolution of career counseling theory', in P.J. Hartung (ed.), Career counselling. Definitions and new directions, Psychological Association, 119th Annual meeting, Washington, D.C, American.

Swanepoel, E., 2012. Studente misbruik Ritalin vir eksamenskrvf, besigtig op 21 Apr 014, 152.111.1.88/argief/berigte/beeld/2012/08/18/B1/7/tesritalinmisbruik. htm

Teddlie, C. \& Tashakkori, A., 2009, Foundations of mixed methods research: Integrating quantitative and qualitative approaches in the social and behavioral sciences, Sage, Los Angeles, CA.

Tracey, T.J.G. \& Hopkins, N., 2001, 'The correspondence of interests and abilities with occupational choice', Journal of Counseling Psychology 48, 178-189. http:// dx.doi.org/10.1037/0022-0167.48.2.178

Vosloo, H.N., Coetzee, N. \& Claassen, N.C.W., 2000, Handleiding vir die Differensiële Aanlegtoetse Vorm S (DAT-S), RGN, Pretoria, Suid-Afrika.

Wink, J., 2005, Critical pedagogy: Notes from the real world, Pearson, Boston, MA. 